Sugerowane cytowanie:

Sienkiewicz-Małyjurek, K. (2020). Odporność i przedsiębiorczość w zarządzaniu kryzysowym. W: M. Ćwiklicki, K. Sienkiewicz-Małyjurek, (red.). Ekonomia Społeczna. Przedsiębiorczość społeczna w czasie kryzysu (s. 22-36).

Kraków: Uniwersytet Ekonomiczny w Krakowie. https://doi.org/10.15678/ES.2020.2.03

\title{
Odporność i przedsiębiorczość w zarządzaniu kryzysowym
}

\author{
Katarzyna Sienkiewicz-Małyjurek
}

Streszczenie: Koncepcje odporności i przedsiębiorczości w zarządzaniu kryzysowym mogą przyczynić się do zwiększenia możliwości sprostania zagrożeniom i sytuacjom kryzysowym. Dotychczasowe badania ukierunkowane są w większości przypadków na wyjaśnienie wpływu odporności i przedsiębiorczości na zarządzanie kryzysowe, a sporadycznie podejmowane są próby ustalenia, jak wzajemnie oddziałują one między sobą. Z tego względu za cel niniejszego artykułu przyjęto usystematyzowanie wiedzy w zakresie roli odporności i przedsiębiorczości w zarządzaniu kryzysowym oraz wzajemnych relacji między tymi koncepcjami. Został osiągnięty na podstawie systematycznego przeglądu literatury, który został przeprowadzony w oparciu o metodykę PRISMA Group. W wyniku przeprowadzonych analiz zidentyfikowano cechy i wpływ zarówno odporności, jak i przedsiębiorczości na zarzadzanie kryzysowe, znaczenie tych koncepcji w ujęciu społecznym, a także wzajemne interakcje pomiędzy nimi. Uzyskane wyniki wskazują, że sytuacje kryzysowe stanowią akceleratory zmian stwarzające szanse na rozwój przedsiębiorczości zarówno w perspektywie społecznej, jak i w działaniach organizacji publicznych i prywatnych. Odporność i przedsiębiorczość współoddziałują, wspólnie budując lepsze możliwości organizacji do radzenia sobie z zagrożeniami.

Słowa kluczowe: odporność; odporność społeczna; przedsiębiorczość; przedsiębiorczość społeczna; zarządzanie kryzysowe; systematyczny przegląd literatury

Kody JEL: $\quad H 12, H 75, H 84, L 38$

\section{Wstęp}

Odporność jest to zdolność systemu lub społeczeństwa narażonego na zagrożenia do adaptacji do nowej sytuacji poprzez przeciwstawianie się lub wprowadzanie zmian w celu utrzymania akceptowalnego poziomu funkcjonowania (United Nations, 2007). W zarządzaniu kryzysowym koncepcja ta posiada kluczowe znaczenie, gdyż stanowi nowy sposób podejścia do badania zagrożeń i ich skutków (Baker i Refsgaard, 2007; Alexander, 2013). Odnosi się ona do budowania i rozwoju zdolności umożliwiających radzenie sobie w sytuacjach kryzysowych oraz rozwoju społeczno-organizacyjnym w oparciu o istniejące relacje wewnętrze i zewnętrzne. Budowaniu takich zdolności sprzyja przedsiębiorczość, która w ogólnym znaczeniu oznacza proces łączenia zasobów w celu tworzenia wartości zarówno materialnych, jak i niematerialnych (Bernier i Hafsi, 2007; Canestrino i in., 2020; Ćwiklicki, 2017; Steyaert i Katz, 2004). W zarządzaniu kryzysowym przedsiębiorczość ma charakter systemowy, zależy od uwarunkowań sytuacyjnych i może przyczynić się do zwiększenia możliwości świadczenia usług publicznych (Bernier i Hafsi, 2007). 
Dotychczasowe badania w zakresie współoddziaływania odporności i przedsiębiorczości w zarządzaniu kryzysowym są jednakże dopiero na początkowym etapie rozwoju. Choć odporność w zarządzaniu kryzysowym stanowi kluczową koncepcję wyjaśniającą dlaczego niektóre społeczności lepiej radzą sobie z zagrożeniami, istnieje niedosyt badań w zakresie powiązania jej z przedsiębiorczością (Linnenluecke i McKnight, 2017). Stosunkowo niewiele opracowań poświęcono również przedsiębiorczości w ujęciu zarządzania kryzysowego (Doern i in., 2019; Duchek, 2018). Wskazywana jest jednak potrzeba pogłębienia badań w zakresie wykorzystania koncepcji odporności i przedsiębiorczości w zarządzaniu kryzysowym, gdyż mogą się one przyczynić do lepszego radzenia sobie z wyzwaniami społecznymi (Gur i in., 2020; Korber i McNaughton, 2018; Vlasov i in., 2018). Istnieje zatem niewystarczające rozpoznanie teoretyczno-empiryczne współoddziaływania koncepcji odporności i przedsiębiorczości w sytuacjach kryzysowych, np. w czasie powodzi, czy pandemii typu COVID-19. Na tej podstawie za cel niniejszego artykułu przyjęto usystematyzowanie wiedzy w zakresie roli odporności i przedsiębiorczości w zarządzaniu kryzysowym oraz wzajemnych relacji między tymi koncepcjami.

\section{Kontekst badawczy}

Zarządzanie kryzysowe jest to „działalność organów administracji publicznej będąca elementem kierowania bezpieczeństwem narodowym, która polega na zapobieganiu sytuacjom kryzysowym, przygotowaniu do przejmowania nad nimi kontroli w drodze zaplanowanych działań, reagowaniu w przypadku wystąpienia sytuacji kryzysowych, usuwaniu ich skutków oraz odtwarzaniu zasobów i infrastruktury krytycznej" (Dz.U. 2007, 89, 590 - art. 2). Źródłem sytuacji kryzysowych są zagrożenia (np. klęski żywiołowe, pandemie, awarie techniczne, ataki terrorystyczne, sabotaż, masowa przemoc i demonstracje), w stosunku do których nie udało się wprowadzić odpowiednich działań zabezpieczających, a skala tych zagrożeń przekroczyła możliwości działania administracji publicznej. Jak pisze Kitler (2010, s. 83), zarządzanie kryzysowe jest:

- integralną częścią zarządzania organizacją (systemem) w ogóle;

- dziedziną i specyficznym rodzajem zarządzania bezpieczeństwem w ogóle, w tym bezpieczeństwem narodowym;

- zarządzaniem organizacją pod presją, w stanie ryzyka;

- rozwiązywaniem napiętych sytuacji przez zespolenie wysiłków różnych podmiotów wykonawczych, gdy nie są w stanie rozwiązać ich w trybie działań rutynowych;

- działaniem na rzecz obniżania napięć i przeciwdziałania konfliktom lub sytuacjom trudnym o charakterze niekonfliktowym;

- przeciwdziałaniem eskalacji kłopotliwych zjawisk;

- działalnością polegającą na przywracaniu stanu normalnego lub utrzymaniu tego stanu mimo wystąpienia symptomów sytuacji kryzysowej.

W procesie zarządzania kryzysowego można zidentyfikować dwie zasadnicze fazy: stabilizacji i realizacji (Hossain i Kuti, 2010; Sienkiewicz-Małyjurek, 2015).

W przypadku każdej sytuacji kryzysowej istnieje wiele sposobów poprowadzenia działań, ale nie ma możliwości identyfikacji ich wszystkich. Metody te stanowią zbiór pomysłów podmiotów uczestniczących w działaniach. Każda z zaangażowanych organizacji na swój indywidualny sposób postrzega możliwości postępowania z zagrożeniem i posiada własną koncepcję działania. Nie istnieje jedno właściwe i wystarczające rozwiązanie, a jedynie traf- 
niejsze lub mniej dokładne interpretacje danej sytuacji. Jednakże w sytuacjach kryzysowych decydenci mają tylko jedną szansę na podjęcie adekwatnej do danej sytuacji decyzji. Każda z takich decyzji pociąga za sobą określone konsekwencje, które generują kolejny zbiór możliwych przedsięwzięć. Konsekwencje podejmowanych decyzji mogą mieć zarówno pozytywny, jak i negatywny wpływ na przebieg działań. Nie jest możliwe ich wcześniejsze sprawdzenie, a ich skutków nie da się odwrócić. W zarządzaniu kryzysowym liczy się ponadto czas działania, a testowanie rozwiązań może go jedynie wydłużyć. Możliwe jest jedynie wcześniejsze analizowanie potencjalnych możliwości i ich konsekwencji (Kożuch i Sienkiewicz-Małyjurek, 2015b; Metcalfe, 2005;Tatham i Houghton, 2011). Problem mogą stanowić również związki między zagrożeniami, gdyż jedno zagrożenie może generować następne. Dodatkowo istnieje wiele problemów o charakterze operacyjnym, które wpływają na efekty prowadzenia działań. Należą do nich m.in.: awarie sieci komunikacyjnych, utrudniony dostęp do danych i informacji, brak zintegrowanych baz danych, ograniczenia zasobowe, brak wiedzy i doświadczenia, itp. (Kożuch i Sienkiewicz-Małyjurek, 2015a; Kożuch i Sienkiewicz-Małyjurek, 2015b; Kusumasari i in., 2010). Wszystkie te czynniki mogą być źródłem problemów organizacyjnych i mogą generować luki i wąskie gardła w procesie realizacji działań.

Złożoność problematyki zarządzania kryzysowego wskazuje, że istotą zarządzania kryzysowego jest szybka identyfikacja zagrożeń i radzenie sobie z nimi w celu niedopuszczenia do wystąpienia sytuacji kryzysowej. Jeżeli już ona wystąpi, to istnieje potrzeba poprowadzenia działań w taki sposób, aby zminimalizować straty, kontrolować sytuację, w jak najkrótszym czasie powrócić do stanu pierwotnego bądź lepszego, a także doskonalić możliwości działania na podstawie procesów uczenia się. Realizacja tych przedsięwzięć jest jednak niezmiernie trudna. Poszukiwanie na przestrzeni ostatnich lat skutecznych sposobów radzenia sobie z zagrożeniami i złożonością zarządzania kryzysowego zwróciły uwagę na znaczenie odporności i przedsiębiorczości w analizowanym obszarze (Doern i in., 2019; Linnenluecke i McKnight, 2017; Sienkiewicz-Małyjurek, 2015).

\section{Metodyka badawcza}

Cel niniejszego artykułu, którym jest usystematyzowanie wiedzy w zakresie roli odporności i przedsiębiorczości w zarządzaniu kryzysowym oraz wzajemnych relacji między tymi koncepcjami został osiągnięty na podstawie systematycznego przeglądu literatury. Przegląd ten przeprowadzono w sierpniu 2020 r. w oparciu o bazy danych Scopus i Web of Science w celu wyszukania publikacji o jak najwyższych walorach naukowych wynikających z rygorystycznego procesu recenzowania. W tym celu wykorzystano metodykę PRISMA Group (Moher i in. 2009). Przeprowadzony proces badawczy został zilustrowany na rysunku 1.

Podstawowymi słowami kluczowymi wykorzystanymi w systematycznym przeglądzie literatury były: „entrepreneur* i „resilien*”. W tym połączeniu wyszukano następnie słowa: „emergenc*", "disaster*" i "crisis*". Wyszukiwanie przeprowadzono w tytułach, abstraktach i słowach kluczowych, bez ograniczenia czasowego oraz we wszystkich rodzajach publikacji, tj. artykułach, publikacjach konferencyjnych, książkach i rozdziałach w pracach zbiorowych. Uzyskano w ten sposób zbiór publikacji teoretycznych i empirycznych odnoszących się do analizowanej problematyki, który objął 577 tekstów. Następnie przeprowadzono weryfikację uzyskanych prac i wyeliminowano artykuły dublujące się, co wynikało z wyszukiwania w dwóch bazach. W rezultacie zredukowano liczbę branych pod uwagę publikacji do 343. Ponadto, na podstawie analizy abstraktów i skanowania tekstów, z badań wyłączono te publikacje, które nie były 


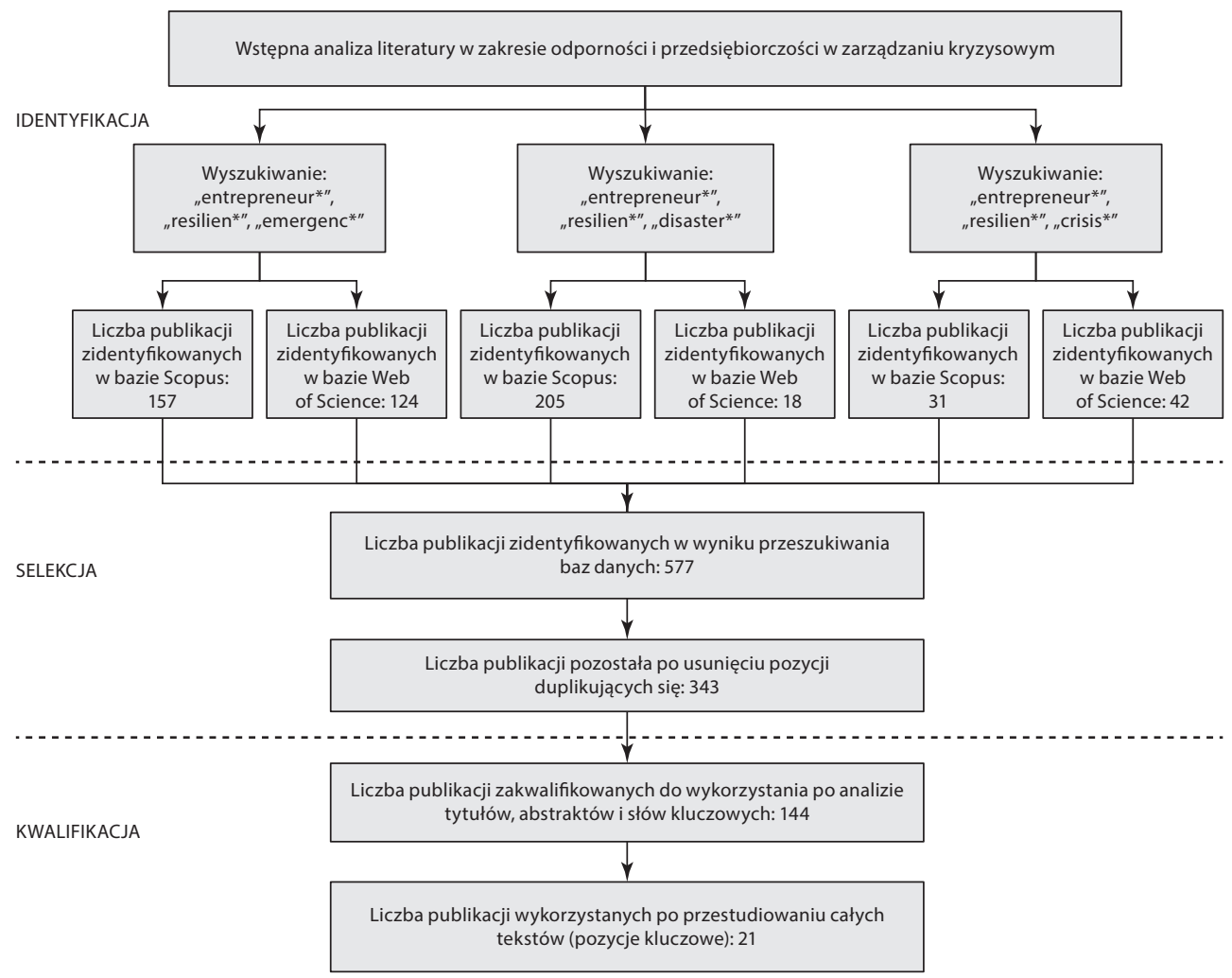

Rysunek 1. Zastosowany proces badawczy

Źródło: opracowanie własne na podstawie (Moher i in. 2009).

zgodne z analizowanym obszarem. Proces ten umożliwił uzyskanie 144 publikacji, które po przestudiowaniu ograniczono do 21 tekstów. Zostały one przyjęte jako kluczowe w prowadzonych analizach. Ich zestawienie przedstawiono w tabeli 1.

\section{Tabela 1. Zestawienie kluczowych publikacji nt. odporności i przedsiębiorczości w zarządzaniu kryzysowym zidentyfikowanych w ramach systematycznego przeglądu literatury}

\begin{tabular}{|l|l|l|}
\hline \multicolumn{1}{|c|}{ Źródło } & \multicolumn{1}{|c|}{ Cel artykułu } & \multicolumn{1}{|c|}{ Metoda badawcza } \\
\hline Bullough i in. (2014) & $\begin{array}{l}\text { zbadanie wpływu dostrzeganego niebezpieczeń- } \\
\text { stwa i odporności na przedsiębiorcze zamiary } \\
\text { podejmowane w niesprzyjających warunkach na } \\
\text { przykładzie Afganistanu }\end{array}$ & badania ankietowe przeprowadzone \\
\hline Gray i in.(2014) & $\begin{array}{l}\text { zbadanie, jak czynniki zewnętrzne i zdarzenia } \\
\text { losowe wpływają na rozpoznawanie i wykorzysty- } \\
\text { wanie szans w zakresie wyzwań gospodarczych i } \\
\text { społecznych, które wymagają przedsiębiorczych } \\
\text { rozwiązań }\end{array}$ & studium przypadku \\
\hline
\end{tabular}




\begin{tabular}{|c|c|c|}
\hline Źródło & Cel artykułu & Metoda badawcza \\
\hline Korsgaard i in. (2016) & $\begin{array}{l}\text { pogłębienie wiedzy na temat przedsiębiorczości, } \\
\text { która może pomóc naukowcom, decydentom i } \\
\text { praktykom w opracowaniu przedsiębiorczych reakcji } \\
\text { na kryzys gospodarczy, środowiskowy i społeczno- } \\
\text {-przestrzenny }\end{array}$ & podejście koncepcyjne \\
\hline $\begin{array}{l}\text { Williams i Shepherd } \\
\text { (2016) }\end{array}$ & $\begin{array}{l}\text { zrozumienie roli wyłaniających się organizacji w } \\
\text { reagowaniu na katastrofy i budowaniu odporności } \\
\text { w Haiti } 2010\end{array}$ & studium przypadku \\
\hline Diržytè i in. (2017) & $\begin{array}{l}\text { zidentyfikowanie czynników wrażliwości } \\
\text { społeczno-ekonomicznej, znaczenia wzmocnienia } \\
\text { odporności i zmniejszenia nierówności społeczno- } \\
\text {-ekonomicznych }\end{array}$ & $\begin{array}{l}\text { badanie ankietowe przeprowadzone w } 2016 \text { roku } \\
\text { (próba reprezentatywna, } n=1001 \text { ) }\end{array}$ \\
\hline $\begin{array}{l}\text { Gajendran i Olorun- } \\
\text { toba (2017) }\end{array}$ & $\begin{array}{l}\text { analiza wpływu zarządzania, jako mechanizmu } \\
\text { koordynacji społecznej na odporność w fazie } \\
\text { odbudowy; analiza relacji między interesariuszami, } \\
\text { którzy wpływają na przyszłe trajektorie odporności } \\
\text { i kierują nimi }\end{array}$ & studium przypadku \\
\hline Kirkwood i in. (2017) & $\begin{array}{l}\text { zbadanie doświadczeń w zakresie ekoprzedsię- } \\
\text { biorczości w czasie serii trzęsień ziemi w latach } \\
\text { 2010-2011 w Christchurch w Nowej Zelandii }\end{array}$ & $\begin{array}{l}\text { longitudinalne studium przypadku Just Organic Ltd. } \\
\text { w okresie pięciu lat, obejmującym okres przed i po } \\
\text { trzęsieniach ziemi; dane zebrano w drodze dwóch } \\
\text { dogłębnych wywiadów osobistych z ekoprzed- } \\
\text { siębiorcá, a także w wyniku analizy wielu e-maili } \\
\text { i telefonów }\end{array}$ \\
\hline $\begin{array}{l}\text { Linnenluecke } \\
\text { i McKnight (2017) }\end{array}$ & $\begin{array}{l}\text { zbadanie warunków, w jakich przedsiębiorczość } \\
\text { związana z klęskami żywiołowymi przyczynia się do } \\
\text { odporności społecznej }\end{array}$ & studia przypadków \\
\hline $\begin{array}{l}\text { Monllor i Murphy } \\
\text { (2017) }\end{array}$ & $\begin{array}{l}\text { zrozumienie, w jaki sposób klęski żywiołowe wpły- } \\
\text { wają na przedsiębiorczość }\end{array}$ & krytyczny przegląd literatury \\
\hline Morrison i in. (2017) & $\begin{array}{l}\text { zrozumienie procesów, dzięki którym przedsiębiorcy } \\
\text { społeczni mogą przyczyniać się do odporności i } \\
\text { zrównoważonego rozwoju społeczności }\end{array}$ & studia przypadków \\
\hline Roundy i in. (2017) & $\begin{array}{l}\text { zbadanie dynamiki ekosystemów, źródeł rozbieżno- } \\
\text { ści i ich wpływu na odporność ekosystemów }\end{array}$ & krytyczny przegląd literatury \\
\hline Williams i in. (2017) & $\begin{array}{l}\text { przegląd literatury dotyczącej zarządzania kryzy- } \\
\text { sowego i odporności oraz omówienie możliwości } \\
\text { zarówno integracji, jak i rozwoju tych nurtów } \\
\text { badawczych }\end{array}$ & krytyczny przegląd literatury \\
\hline Cameron i in. (2018) & \begin{tabular}{|l|} 
zbadanie zmian w systemie wartości społeczności \\
dotkniętej trzęsieniami ziemi i możliwości, jakie \\
stwarza niestabilne otoczenie dla przedsiębiorczości \\
w ciągu pięciu lat po trzęsieniach ziemi w Christ- \\
church w Nowej Zelandii w 2010 i 2011 roku
\end{tabular} & $\begin{array}{l}\text { pogłębione wywiady z } 45 \text { osobami zaangażowa- } \\
\text { nymi w działania przedsiębiorcze realizowane } \\
\text { w celach komercyjnych lub społecznych }\end{array}$ \\
\hline Duchek (2018) & $\begin{array}{l}\text { zidentyfikowanie kluczowych czynników w procesie } \\
\text { rozwoju odporności i przedstawienie modelu odpor- } \\
\text { ności przedsiębiorczości, który może posłużyć jako } \\
\text { punkt wyjścia do przyszłych badań empirycznych }\end{array}$ & przegląd literatury i metoda biograficzna \\
\hline
\end{tabular}




\begin{tabular}{|c|c|c|}
\hline Źródło & Cel artykułu & Metoda badawcza \\
\hline Grube i Storr (2018) & $\begin{array}{l}\text { zbadanie zachowań i praktyk przedsiębiorców } \\
\text { po katastrofach oraz ustalenie ich roli w procesie } \\
\text { odbudowy w Nowym Orleanie po huraganie Katrina } \\
\text { i w Tuscaloosa oraz Joplin po wystąpieniu tornad }\end{array}$ & badania terenowe przeprowadzone \\
\hline $\begin{array}{l}\text { Korber i McNaughton } \\
\text { (2018) }\end{array}$ & $\begin{array}{l}\text { przegląd istniejącej literatury z zakresu odporności i } \\
\text { przedsiębiorczości }\end{array}$ & systematyczny przegląd literatury \\
\hline $\begin{array}{l}\text { Manfield i Newey } \\
\text { (2018) }\end{array}$ & $\begin{array}{l}\text { zbadanie założeń dotyczących natury odporności i } \\
\text { wybranie najbardziej odpowiednich dla kontekstu } \\
\text { przedsiębiorczości }\end{array}$ & krytyczny przegląd literatury \\
\hline Martinelli i in. (2018) & $\begin{array}{l}\text { zbadanie formatywnych wymiarów odporności } \\
\text { organizacyjnej - zdolności dynamicznych i kapitału } \\
\text { społecznego - przejawianych przez przedsiębiorców } \\
\text { handlu detalicznego w obliczu klęsk żywiołowych } \\
\text { (dotkniętych trzęsieniem ziemi w Emilii w } 2012 \text { r.) }\end{array}$ & $\begin{array}{l}\text { badania fokusowe i częściowo ustrukturyzowane } \\
\text { wywiady przeprowadzone wśród ośmiu małych } \\
\text { przedsiębiorców detalicznych }\end{array}$ \\
\hline Vlasov i in. (2018) & $\begin{array}{l}\text { zbadanie, w jaki sposób zakorzenienie w miejscu } \\
\text { i w ponadlokalnych sieciach tworzonych oddolnie } \\
\text { wpływa na proaktywną przedsiębiorczość na rzecz } \\
\text { lokalnej odporności }\end{array}$ & krytyczny przegląd literatury \\
\hline Doern i in. (2019) & $\begin{array}{l}\text { zrozumienie związków między przedsiębiorczością a } \\
\text { sytuacjami kryzysowymi }\end{array}$ & krytyczny przegląd literatury \\
\hline Gur i in. (2020) & $\begin{array}{l}\text { zbadanie roli przedsiębiorczości, zaangażowania } \\
\text { interesariuszy i elementów odporności na wybrzeżu } \\
\text { Zatoki Perskiej Stanów Zjednoczonych po wycieku } \\
\text { ropy Deepwater Horizon w } 2010 \text { r. }\end{array}$ & $\begin{array}{l}\text { jakościowa analiza treści artykułów branżowych } \\
\text { dotyczących analizowanego przypadku }\end{array}$ \\
\hline
\end{tabular}

Źródło: opracowanie własne.

Analiza treści przedstawionych w publikacjach ujętych w tabeli 1 była podstawą do zbadania wpływu koncepcji odporności i przedsiębiorczości na zarządzanie kryzysowe oraz relacji pomiędzy nimi.

\section{Wyniki badania}

\subsection{Odporność w zarządzaniu kryzysowym}

Odporność to pojęcie znajdujące szerokie zastosowanie w wielu dyscyplinach naukowych, w tym w naukach fizycznych, ekologii, psychologii, ekonomii, naukach technicznych, czy też naukach społecznych. Rozwój i zrozumienie odporności różnią się nie tylko między dyscyplinami, ale i między kontekstami badawczymi. Nawet w naukach społecznych nurty badawcze różnią się w takich obszarach jak np.: zarządzanie strategiczne, zarządzanie łańcuchem dostaw, zarządzanie kryzysowe, psychologia organizacji (Martinelli i in., 2018; Sienkiewicz-Małyjurek, 2015).

W najbardziej podstawowym znaczeniu odporność oznacza zdolność osób, organizacji lub systemów do radzenia sobie i absorbowania zagrożeń, rozwoju i adaptacji w warunkach nieustannych zmian (Gajendran i Oloruntoba, 2017; Linnenluecke i McKnight 2017; Vlasov i in., 2018). Stanowi ona zdolność, która pozwala na utrzymanie obranego celu, dalsze funkcjonowanie, a nawet rozwój w niekorzystnych warunkach działania. Interdyscyplinarny charakter odporności pozwala na ustalenie jej uniwersalnych cech, do których należą (Kirkwood i in., 2017; Manfield i Newey, 2018; Martinelli i in., 2018): 
- zależność od rodzaju zagrożeń,

- posiadanie dynamicznego, procesowego charakteru umożliwiającego rozwój w czasie,

- uruchomienie procesów uczenia się w trakcie radzenia sobie z zagrożeniami,

- wykorzystanie zagrożeń jako źródła zmian i rozwoju,

- przekształcenie wyzwań w szanse i wykorzystywanie pojawiających się możliwości.

W naukach społecznych powyższe cechy sprawiają, że systemy i organizacje są w stanie sprostać zagrożeniom, a nawet wykorzystać je do skokowego rozwoju. Rozwój i utrzymanie cech odporności opiera się na czterech zdolnościach (Martinelli i in., 2018): poznawczych, behawioralnych, kontekstowych i dynamicznych. Zdolności poznawcze są wynikiem tworzenia sensu i tożsamości ideologicznej, a behawioralne - zróżnicowania zasobów i zwyczajów funkcjonalnych. Zdolności kontekstowe obejmują kapitał społeczny i sieć zasobów zewnętrznych, a dynamiczne z kolei dotyczą tworzenia i modyfikowania bazy zasobów (Martinelli i in., 2018). Podstawy tych zdolności budują rutyny i doświadczenie. Odnoszą się one zarówno do poziomu indywidualnego, organizacyjnego, jak i społecznego, a w zarządzaniu kryzysowym są aktualnie przedmiotem intensywnego zainteresowania badawczego.

Badania nad odpornością w zarządzaniu kryzysowym dotyczą pojedynczych osób, organizacji i sieci, społeczności, miast i regionów, a także mogą mieć charakter międzynarodowy. Badania te koncentrują się przede wszystkim na działaniach organizacji publicznych, których sposób reagowania według struktury i zadań klasyfikuje się następująco (Linnenluecke i McKnight, 2017, p. 170):

- działania ustalone, opierające się na strukturach istniejących przed zagrożeniem, np. w procedurach funkcjonowania służb ratunkowych, szpitali, wydziałów odpowiedzialnych za zarządzanie kryzysowe w jednostkach samorządowych;

- działania rozszerzone, które wykraczają poza istniejące struktury i obejmują jednostki ochotnicze, np. Czerwony Krzyż;

- działania obszerne, które opierają się na istniejących strukturach, ale obejmują nieprzewidziane zadania i dodatkowych uczestników, np. kluby społeczne, kościoły, organizacje publiczne zaangażowane w odbudowę po sytuacji kryzysowej;

- działania wyłaniające się, obejmujące nowe struktury realizujące przedsięwzięcia, które dotychczas nie były podejmowane, np. zespoły ds. oceny szkód powołane w celu zbadania konkretnej sytuacji.

M.K. Linnenluecke i B. McKnight (2017) zidentyfikowali ponadto dwa podstawowe nurty badawcze dotyczące odporności w zarządzaniu kryzysowym. Pierwszy z nich obejmuje badania na temat sposobu wpływania sytuacji kryzysowych na infrastrukturę techniczną, zagrożenia funkcjonowania łańcuchów dostaw i organizacji sektora prywatnego. Ich rezultatem są dobre praktyki w zakresie ciągłości działania, zarządzania w sytuacjach kryzysowych, a także strategii adaptacji w sektorze prywatnym. Drugi nurt badawczy dotyczy działań organizacji publicznych podejmowanych w zarządzaniu kryzysowym. Analizom poddawane są formalne systemy reagowania w przypadku wystąpienia sytuacji kryzysowych oraz zadania i role poszczególnych służb publicznych. Brakuje jednak nurtu obejmującego zaangażowanie firm sektora prywatnego w działania z zakresu zarządzania kryzysowego z perspektywy społecznej (Linnenluecke i McKnight, 2017). Choć badania w takim ujęciu są podejmowane, mają one charakter wybiórczy i niesystematyczny oraz nie stwarzają podstaw do ustalenia, jaką rolę odgrywa społeczność lokalna w działaniach na rzecz zarządzania kryzysowego.

Społeczność obejmuje środowisko lokalne i społeczno-gospodarcze, zlokalizowane na określonym obszarze administracyjnym i powiązane wspólnymi relacjami (Linnenluecke 
i McKnight, 2017; Morrison i in., 2017). Jedną z cech społeczności jest określony poziom odporności na wypadek wystąpienia zagrożeń i sytuacji kryzysowych. Odporność społeczna jest przedmiotem intensywnych badań naukowych i współcześnie wydaje się, że stanowi ona kluczowe zagadnienie w zarządzaniu kryzysowym (Gajendran i Oloruntoba, 2017). Badania w tym zakresie koncentrują się przede wszystkim na sposobach reagowania wspólnot lokalnych na zagrożenia oraz transformacji wynikającej z adaptacji do nowych warunków działania.

Odporność społeczna polega na zdolności jednostek i grup społecznych do przystosowania się do zmieniających się okoliczności funkcjonowania w złożonym środowisku (Linnenluecke i McKnight, 2017; Morrison i in., 2017). Odnosi się ona do niezawodności sieci infrastruktury oraz zdolności wspólnot lokalnych do mobilizacji działań mających na celu ograniczanie zagrożeń i ich skutków. W literaturze wyróżnia się podejście reaktywne i proaktywne do odporności społecznej (Vlasov i in., 2018). Podejście reaktywne odnosi się do radzenia sobie z pojawiającymi się zagrożeniami, a proaktywne do przewidywania zmian i adaptacji do nich na podstawie uruchomienia procesów uczenia się. Oczywistym jest, że podejście proaktywne jest bardziej skuteczne i uznane w badaniach naukowych.

Odporność społeczna ma charakter procesowy, gdyż przedstawia sposób w jaki społeczności przewidują, przygotowują się i reagują na zagrożenie, a następnie wzmacniają swój poziom odporności (Linnenluecke i McKnight, 2017). Kluczowe znaczenie w tym zakresie ma przedsiębiorczość, gdyż pozwala na wypełnienie luk organizacyjnych w procesie zarządzania kryzysowego.

\subsection{Przedsiębiorczość w zarządzaniu kryzysowym}

Przedsiębiorczość to proces łączenia i wykorzystania zasobów w celu tworzenia wartości materialnych i niematerialnych (Canestrino i in., 2020; Ćwiklicki, 2017; Vlasov i in., 2018). Definiowana jest jako zdolność organizacyjna do identyfikowania szans i rozwijania bazy zasobów potrzebnej do ich wykorzystania (Martinelli i in., 2018). Występuje ona zarówno w sektorze prywatnym, jak i publicznym i pozarządowym. Sektor publiczny cechuje się pewną specyfiką, m.in.: ukierunkowaniem nie na zysk, ale na cele społeczne i polityczne; podejmowaniem decyzji nie pod wpływem wymagań rynkowych, ale politycznych; dużym zróżnicowaniem klientów; większą transparentnością działania; unikaniem błędów i ryzyka; tendencją do generowania sztywnych reguł działania itd. Ta specyfika sprawia, że przedsiębiorczość w tym sektorze różni się od przedsiębiorczości prywatnej, a jej kluczowe charakterystyki dotyczą następujących cech (Bernier i Hafsi, 2007, s. 494):

- przedsiębiorczość w sektorze publicznym jest zjawiskiem systemowym, które wymaga wysokiego poziomu współpracy pomiędzy wyspecjalizowanymi podmiotami;

- podmioty koordynujące wspólne działania odpowiadają za ciągłość tych działań i zarządzają nimi, a innowacje wprowadzane są oddolnie;

- menedżerowie średniego szczebla są głównym, ale nie jedynym źródłem kreatywności organizacyjnej, integrują innowacje oddolne ze wspólnymi strategiami działania;

- przedsiębiorczość w sektorze publicznym wymaga przywództwa na szczycie, a główni menedżerowie odgrywają rolę inkubatorów przedsiębiorczości;

- główni menedżerowie ustalają priorytety, podejmują inicjatywy międzyorganizacyjne oraz zachęcają do przedsiębiorczych inicjatyw.

Przedsiębiorczość w sektorze publicznym rozwija się, odgrywa coraz większą rolę w dostarczaniu usług publicznych i równocześnie cieszy się coraz większym zainteresowaniem badawczym. Choć zostało potwierdzone naukowo, że kryzysy najczęściej wpływają negatywnie na 
intencje przedsiębiorcze, w niektórych przypadkach mogą one prowadzić do luk organizacyjnych i dzięki temu stwarzać możliwości rozpoczęcia działalności gospodarczej lub przedsiębiorczych inicjatyw (Doern i in., 2019; Linnenluecke i McKnight, 2017). Takie inicjatywy mogą mieć zarówno charakter komercyjny, jak również społeczny, ukierunkowany na pomoc poszkodowanym społecznościom. Ponadto, jak wskazują dotychczasowe badania, reagowanie w sytuacjach kryzysowych w dużym stopniu zależy od zdolności przedsiębiorców do reorganizacji lub mobilizacji zasobów i możliwości (Martinelli i in., 2018; Korsgaard i in. 2016). Przedsiębiorczość w zarządzaniu kryzysowym przejawia się następująco (Linnenluecke i McKnight, 2017, s. 168):

- utrzymanie ciągłości działalności gospodarczej, np. firmy utrzymujące działalność w czasie sytuacji kryzysowej lub ponownie otwierające działalność wkrótce po takiej sytuacji w celu utrzymania źródeł przychodów i rentowności;

- regulowanie reakcji organizacyjnych poprzez aktywowanie ukrytych struktur, np. firmy mogą przyjąć inną konfigurację strukturalną do prowadzenia działań w czasie sytuacji kryzysowej;

- improwizowanie, np. centra handlowe mogą zmienić się na schroniska ad hoc;

- wyłanianie się, np. zastosowanie nowych sposobów reagowania na sytuację kryzysową, a także tworzenie nowych przedsięwzięć w celu uzupełnienia braków w zasobach.

Według J. Monllora i P. J. Murphy'ego (2017) agencje rządowe i organizacje pozarządowe są podstawowymi podmiotami w zarządzaniu kryzysowym, ale lokalni przedsiębiorcy z pewnością mają głębszą wiedzę społeczną, która stwarza podstawy do identyfikacji problemów i realizacji przyjętych rozwiązań. Przedsiębiorcy ci posiadają wiedzę o poziomie gospodarki lokalnej, potrzebach społeczno-gospodarczych, a także rozumieją lokalną kulturę społeczną. Wiedza taka stwarza warunki do wykorzystania zagrożeń i sytuacji kryzysowych do rozwiązywania problemów i identyfikowania stwarzanych przez nie możliwości. Odnoszą się one przede wszystkim do luk organizacyjnych w formalnych systemach reagowania na zagrożenia i sytuacje kryzysowe, np. w sytuacji niewydolności systemów ratowniczych, niewystarczającej pomocy logistycznej społeczeństwu, zniszczonej infrastruktury technicznej (Linnenluecke i McKnight, 2017). W takich warunkach tworzą się szanse dla rozwoju przedsiębiorczości społecznej, ukierunkowanej na wypełnienie tych luk.

Przedsiębiorczość społeczna obejmuje szeroki zakres działań prowadzonych przez osoby lub grupy w celu dostarczenia korzyści społeczeństwu (Canestrino i in. 2020; Duchek, 2018; Frączkiewicz-Wronka i Wronka-Pośpiech, 2018; Gray i in., 2014; Morrison i in., 2017). Określa się ją jako działania i procesy podejmowane w celu „odkrywania, definiowania i wykorzystywania możliwości w celu zwiększenia bogactwa społecznego poprzez tworzenie nowych przedsięwzięć lub zarządzanie istniejącymi organizacjami w innowacyjny sposób" (Zahra i in., 2009, s. 519). Stanowi ona siłę napędową innowacji społecznych, zmienia wiedzę i informacje w działania ukierunkowane na realizację zidentyfikowanych potrzeb. W czasie sytuacji kryzysowych mogą pojawić się m.in. potrzeby dostarczenia społecznościom kluczowych zasobów (np. żywności i wody, środków czystości, leków). Potrzeby te mogą zostać zrealizowane przez lokalnych przedsiębiorców, co w rezultacie utrzyma przepływy towarów i usług oraz zapewni im ciągłość biznesową. Ponadto lokalni przedsiębiorcy mogą również angażować się w usuwanie awarii infrastruktury technicznej (Doern i in., 2019; Linnenluecke i McKnight, 2017). W rezultacie przedsiębiorcy społeczni mogą kreować warunki do utrzymania i rozwoju odporności społecznej, gdyż stwarzają dodatkowy kanał dystrybucji produktów potrzebnych społeczności i zapewniają poczucie stabilności w dynamicznych i zmiennych warunkach działania (Grube 
i Storr, 2018; Cameron i in., 2018). Badania przeprowadzone przez J. Monllora i P. J. Murphy'ego (2017) wskazują, iż zagrożenia i sytuacje kryzysowe mogą wręcz generować rozwój przedsiębiorczości społecznej, która będzie z kolei budowała odporność społeczną.

\subsection{Odporność a przedsiębiorczość}

W zarządzaniu kryzysowym odporność budowana na podstawie przedsiębiorczości odnosi się zdolności organizacji sektora publicznego i prywatnego oraz społeczności do sprostania zagrożeniom w wyniku inicjatyw podjętych w celu realizacji zarówno działań prewencyjnych, jak i pomocowych oraz naprawczych. Zdolności te odnoszą się do umiejętności zarządzania zmianami i mobilizacji zasobów. Badania wskazują, że szczególną rolę w tym zakresie odgrywają małe przedsiębiorstwa, które pomagają w dostosowaniu działań całego systemu reagowania do sytuacji kryzysowych poprzez rozwój potrzebnych przedsięwzięć i wykorzystanie możliwości wynikających ze specyfiki lokalnej (Gur i in., 2020). Ich zdolności do efektywnego reagowania na sytuacje kryzysowe i angażowania się w działania transformacyjne w celu wykorzystania przełomowych zdarzeń, które potencjalnie mogą zagrażać ich przetrwaniu, buduje zarówno odporność tych organizacji, jak i odporność społeczną (Frączkiewicz-Wronka i Wronka-Pośpiech, 2018; Vlasov i in., 2018). Według Linnenluecke i McKnight (2017) każdy rodzaj przedsiębiorczości związanej z zagrożeniami i sytuacjami kryzysowymi pozytywnie przyczynia się do wzmocnienia odporności społeczności tylko wtedy, gdy zwiększa zdolność tej społeczności do lepszego radzenia sobie z takimi sytuacjami i powrotu do stanu stabilizacji.

W badaniach wskazuje się również na istnienie odpornej przedsiębiorczości, gdzie odporność rozumiana jest jako jedna z pięciu kluczowych cech przedsiębiorczości (Duchek, 2018; Manfield i Newey, 2018). Definiowana jest ona jako zdolność przedsiębiorców do przewidywania potencjalnych zagrożeń, skutecznego radzenia sobie z nieoczekiwanymi zdarzeniami i dostosowaniem się do zmian celem zwiększenia możliwości przetrwania i rozwoju (Duchek, 2018). Większość badań w tym zakresie skupia się na poziomie indywidualnym. Analizom poddawane są cechy przedsiębiorców, a w tym elastyczność, motywacja, wytrwałość, optymizm, doświadczenie (Doern i in., 2019; Duchek, 2018). Wskazuje się również na wpływ czynników zewnętrznych na możliwości budowania odpornej przedsiębiorczości, ale w mniejszym stopniu badaniom poddawany jest sposób, w jaki jednostki, organizacje lub całe społeczności reagują na zagrożenia i sytuacje kryzysowe. Dotychczasowe badania i analizy wskazują, że odporność przedsiębiorczości w badanym obszarze przejawia się poprzez wdrażanie zmian i rozwój dzięki posiadanym zasobom i zależy zarówno od rodzaju zagrożenia, jak i od fazy zarządzania kryzysowego (Doern i in., 2019; Martinelli i in., 2018). Co więcej, sytuacje kryzysowe wpływają na wzrost przedsiębiorczości tylko wtedy, gdy istnieje konieczność podjęcia określonych działań. Wynika to z niepewności sytuacyjnej, która zwiększa obawę przed niepowodzeniem i może zmniejszać przejawy przedsiębiorczości. Jednakże w sytuacji bez wyjścia, gdy przedsiębiorcy muszą stanąć na wysokości zadania, a ich działania wynikają z konieczności, przedsiębiorczość ma szansę na rozwój. Po zażegnaniu zagrożenia, szanse wynikające z podjętych działań mogą być postrzegane jako bardziej realne, co może generować dalszy rozwój przedsiębiorczości (Monllor i Murphy, 2017). Możliwe jest nawet, że pewne zmiany i rozwój odporności nie mogłyby zaistnieć, gdyby nie wystąpiła sytuacja kryzysowa.

Według S. Korbera i R. B. McNaughtona (2018), relacje między odpornością a przedsiębiorczością mają charakter dwustronny. Odporność, jako cecha osób, organizacji, społeczności czy też regionów, skłania do podejmowania nowych wyzwań i stawiania czoła przeciwnościom. Stymuluje zatem zachowania przedsiębiorcze. Zachowania takie mogą mieć różnorodny prze- 
bieg i efekt, mogą zakończyć się olbrzymim sukcesem, albo wręcz porażką. Takie doświadczenia stanowią źródło nowej wiedzy, która wzmacnia odporność. Antecedencjami odpornej przedsiębiorczości są indywidualne cechy osób i organizacji, które wpływają na obie badane koncepcje. Z tego względu kapitał społeczny jest kluczowym aspektem w zrozumieniu powiązań między działalnością przedsiębiorczą a odpornością (Morrison i in., 2017), począwszy od skali mikro, poprzez mezo, aż do makro (Korber i McNaughton, 2018). Rozwój odporności i przedsiębiorczości przeplata się i obie koncepcje korzystają z brikolażu i improwizacji (Doern i in., 2019; Gray i in., 2014). Takie zdolności pozwalają znaleźć odpowiednie rozwiązanie w czasie zagrożenia, gdy zasoby są ograniczone i liczy się każda minuta.

\section{Zakończenie}

Zagrożenia i sytuacje kryzysowe stanowią katalizatory zmian (Cameron i in., 2018). Testują odporność organizacji publicznych i pozarządowych, przedsiębiorstw prywatnych, czy też społeczności lokalnych. Stwarzają okoliczności, z którymi podmioty te muszą sobie radzić, mając w dyspozycji jedynie posiadane zasoby i próbując je wykorzystać w nowy sposób. Z drugiej strony kreują możliwości szybkiego rozwoju przedsiębiorczych zachowań, które nie byłyby możliwe w okresie stabilizacji, gdy przedsiębiorcy społeczni i prywatni nie mają zbyt wiele możliwości do włączenia się w działania podejmowane przez organy administracji publicznej na rzecz zarządzania kryzysowego. W czasie zagrożenia, kiedy zaplanowane przez administrację publiczną działania okażą się niewystarczające, powstają warunki do rozwoju przedsiębiorczości dostosowanej do określonych potrzeb i kontekstu sytuacyjnego. Z tego względu, z jednej strony zagrożenia i sytuacje kryzysowe stanowią wyzwanie, a z drugiej są szansą na wzrost odporności społeczeństwa i organizacji sektora publicznego i prywatnego, a także na znaczny rozwój przedsiębiorczości społecznej. Jednakże badania w zakresie odporności i przedsiębiorczości w zarządzaniu kryzysowym są dopiero w początkowej fazie rozwoju.

Rozważania przedstawione w tym artykule stanowią wkład w usystematyzowanie i rozwój wiedzy w zakresie wpływu koncepcji odporności i podatności na zarządzanie kryzysowe oraz analizują powiązania między nimi. Wskazują, że odporność uważana jest za cechę osób, organizacji i społeczności, która pozwala im radzić sobie z zagrożeniami. Może ona stanowić czynnik napędzający przedsiębiorczość w sytuacjach kryzysowych. Z kolei przedsiębiorczość, jako zdolność do wykorzystania zasobów w odpowiedni sposób oraz w odpowiednim miejscu i czasie, buduje odporność na przyszłe zagrożenia, nawet w przypadku poniesienia porażki. W artykule tym została podkreślona rola sektora prywatnego i społeczności lokalnych w radzeniu sobie w sytuacjach kryzysowych. Ta tematyka stanowi interesujący i perspektywiczny obszar badawczy, gdyż dotychczasowe badania w tym zakresie skupiają się głównie na zadaniach organizacji sektora publicznego.

Wnioski uzyskane w wyniku przeprowadzonych rozważań mają zarówno implikacje teoretyczne, jak i praktyczne. Z teoretycznej perspektywy wskazują na znaczenie współpracy międzysektorowej, udziału przedsiębiorstw prywatnych i partycypacji społecznej w zarządzaniu w sytuacjach kryzysowych. Stanowią również informację dla decydentów zarządzania kryzysowego, iż potrzebne jest włączenie w działania podmiotów spoza administracji publicznej. Systematyczny przegląd literatury umożliwił ponadto zidentyfikowanie następujących pytań badawczych, które wymagają w przyszłości poszukiwania odpowiedzi zarówno w postaci analiz teoretycznych, jak i empirycznych: 
1. Jakie czynniki przedsiębiorczości i odporności należy uwzględnić w badaniach dotyczących ich współoddziaływania w zarządzaniu kryzysowym? W dotychczasowych badaniach uwzględniane były wybrane czynniki i jedynie na określonych poziomach analizy (indywidualnym, organizacyjnym, społecznym, itd.). Wydaje się, że holistyczne podejście do badania odporności i przedsiębiorczości pozwoliłoby na zidentyfikowanie nowych możliwości sprostania sytuacjom kryzysowym.

2. Jakie determinanty motywują przedsiębiorstwa prywatne i społeczeństwo do uczestniczenia w działaniach z zakresu zarzadzania kryzysowego? Jak zwiększyć tę motywację? Niezaprzeczalnym jest, że przedsiębiorczość społeczna i prywatna w znacznym stopniu przyczynia się do zwiększenia skuteczności zarządzania kryzysowego. Wciąż jednak potrzebne są pogłębione badania, w jaki sposób zwiększyć współpracę międzysektorową w tym zakresie.

3. Jak oceniać poziom i wpływ przedsiębiorczości na zarządzanie kryzysowe? Istnieje więcej badań na temat pomiaru odporności, niż przedsiębiorczości w zarządzaniu kryzysowym. Choć rola przedsiębiorczości w tym zakresie została wstępnie rozpoznana, jak zaznaczono już w drugiej propozycji badawczej, wciąż istnieje potrzeba systemowego podejścia do jej oceny, co umożliwiłoby ustalenie, czy są jeszcze możliwości jej zwiększenia i w jaki sposób.

4. W jaki sposób oceniać współoddziaływanie odporności i przedsiębiorczości w zarządzaniu kryzysowym? Jakie metody w tym celu wykorzystać? W każdej z tych koncepcji stosowane są odmienne podejścia do ich oceny. Pojawia się zatem potrzeba integracji tych podejść lub opracowania nowych metod syntetycznego pomiaru odporności i przedsiębiorczości.

\section{Literatura}

Abbasi, A., Kapucu, N. (2012). Structural Dynamics of Organizations during the Evolution of Interorganizational Networks in Disaster Response. Journal of Homeland Security and Emergency Management, 9(1). https://doi. org/10.1515/1547-7355.1975

Alexander, D.E. (2013). Resilience and disaster risk reduction: An etymological journey. Natural Hazards and Earth System Sciences, 13, 2707-2716. https://doi.org/10.5194/nhess-13-2707-2013

Baker, D., Refsgaard, K. (2007). Institutional development and scale matching in disaster response management. Ecological Economics, 63(2-3), 331-343. https://doi.org/10.1016/j.ecolecon.2007.01.007

Bernier, L., Hafsi, T. (2007). The changing nature of public entrepreneurship. Public Administration Review, 67(3), 488-503. https://doi.org/10.1111/j.1540-6210.2007.00731.x

Boin, A., , t Hart, P. (2010). Organising for Effective Emergency Management: Lessons from Research. Australian Journal of Public Administration, 69, 357-371. https://doi.org/10.1111/j.1467-8500.2010.00694.x

Bullough, A., Renko, M., Myatt, T. (2014). Danger zone entrepreneurs: The importance of resilience and selfefficacy for entrepreneurial intentions. Entrepreneurship: Theory and Practice, 38(3), 473-499. https://doi. org/10.1111/etap.12006

Cameron, T., Moore, K., Montgomery, R., Stewart, E.J. (2018) Creative ventures and the personalities that activate them in a post-disaster setting. Creativity and Innovation Management, 27(3), 335-347. https://doi. org/10.1111/caim.12270

Canestrino, R., Ćwiklicki, M., Magliocca, P., Pawełek, P. (2020). Understanding social entrepreneurship: A cultural perspective in business research. Journal of Business Research, 110, 132-143. https://doi.org/10.1016/j.jbusres.2020.01.006

Celik, S., Corbacioglu, S. (2010). Role of information in collective action in dynamic disaster environments. Disasters, 34(1), 137-154. https://doi.org/10.1111/j.1467-7717.2009.01118.x

Ćwiklicki, M. (2017). Public Entrepreneurship and Its Role in Public Value Creation. Problemy Zarzadzania, 15(1), part 1, 86-96. https://doi.org/10.7172/1644-9584.65.5

Doern, R., Williams, N., Vorley, T. (2019). Special issue on entrepreneurship and crises: Business as usual? An introduction and review of the literature. Entrepreneurship and Regional Development, 31(5-6), 400-412. https:// doi.org/10.1080/08985626.2018.1541590 
Diržyte, A., Rakauskiene, O.G., Servetkiene, V. (2017). Evaluation of resilience impact on socio-economic inequality. Entrepreneurship and Sustainability /ssues, 4(4), 489-501. https://doi.org/ 10.9770/jesi.2017.4.4(7)

Duchek, S. (2018). Entrepreneurial resilience: A biographical analysis of successful entrepreneurs. International Entrepreneurship and Management Journal, 14(2), 429-455. https://doi.org/10.1007/s11365-017-0467-2

Ficoń, K. (2007). Inżynieria zarządzania kryzysowego, Warszawa: BEL Studio.

Frączkiewicz-Wronka, A., Wronka-Pośpiech M. (2018). How Practices of Managing Partnerships Contributes to the Value Creation-Public-Social Partnership Perspective. Sustainability, 10(12), 4816. https://doi. org/10.3390/su10124816

Gajendran, T., Oloruntoba, R. (2017). Governance and resilience: A case of re-development after a bushfire disaster. Technological Forecasting and Social Change, 121, 50-64. https://doi.org/10.1016/j.techfore.2017.03.016

Gray, B.J., Duncan, S., Kirkwood, J., Walton, S. (2014). Encouraging sustainable entrepreneurship in climatethreatened communities: A Samoan case study. Entrepreneurship and Regional Development, 26(5-6), 401430. https://doi.org/10.1080/08985626.2014.922622

Grube, L.E., Storr, V.H. (2018). Embedded entrepreneurs and post-disaster community recovery. Entrepreneurship and Regional Development, 30(7-8), 800-821. https://doi.org/10.1080/08985626.2018.1457084

Gur, F.A., Bendickson, J.S., Madden, L., McDowell, W.C. (2020). Entrepreneurial opportunity recognition in the face of disasters. International Journal of Entrepreneurial Behavior \& Research, 26(4), 671-693. https://doi. org/10.1108/IJEBR-09-2019-0537

Hernantes, J., Ric,h E., Laugé, A., Labaka, L., Sarriegi, J.M. (2013). Learning before the storm: Modeling multiple stakeholder activities in support of crisis management, a practical case. Technological Forecasting and Social Change, 80(9), 1742-1755. https://doi.org/10.1016/j.techfore.2013.01.002

Hossain, L., Kuti, M. (2010). Disaster response preparedness coordination through social networks. Disasters, 34, 755-786. https://doi.org/10.1111/j.1467-7717.2010.01168.x

Kirkwood, J., Dwyer, K., Walton, S. (2017). An ecopreneur's growing resilience after a series of earthquakes. Journal of Enterprising Communities: People and Places in the Global Economy, 11(1), 129-148. https://doi. org/10.1108/JEC-12-2014-0028

Kitler, W. (2010). Bezpieczeństwo narodowe, podstawowe kategorie, dylematy pojęciowe i próba systematyzacji. Zeszyt Problemowy Towarzystwa Wiedzy Obronnej, 1(61), 1-129.

Korber, S., McNaughton, R.B. (2018). Resilience and entrepreneurship: A systematic literature review. International Journal of Entrepreneurial Behaviour and Research, 24(7), 1129-1154. https://doi.org/10.1108/IJEBR-102016-0356

Korsgaard, S., Anderson, A., Gaddefors, J. (2016). Entrepreneurship as re-sourcing: Towards a new image of entrepreneurship in a time of financial, economic and socio-spatial crisis. Journal of Enterprising Communities, 10(2), 178-202. https://doi.org/10.1108/JEC-03-2014-0002

Kożuch, B., Sienkiewicz-Małyjurek, K. (2015a) Information sharing in complex systems: a case study on public safety management. Procedia Social and Behavioral Sciences, 213, 722-727. https://doi.org/10.1016/ j.sbspro.2015.11.493

Kożuch, B., Sienkiewicz-Małyjurek, K. (2015b). Mapowanie procesów współpracy międzyorganizacyjnej na przykładzie działań realizowanych w bezpieczeństwie publicznym, Zarządzanie Publiczne, 3(31), 237-253. https://doi.org/ 10.4467/20843968ZP.15.018.4328

Kuhlicke, C. (2013). Resilience: A capacity and a myth: Findings from an in-depth case study in disaster management research. Natural Hazards, 67(1), 61-76. https://doi.org/10.1007/s11069-010-9646-y

Kusumasari, B., Alam, Q., Siddiqui, K. (2010). Resource capability for local government in managing disaster. Disaster Prevention and Management, 19(4), 438-451. https://doi.org/10.1108/09653561011070367

Linnenluecke, M.K., McKnight, B. (2017). Community resilience to natural disasters: the role of disaster entrepreneurship. Journal of Enterprising Communities: People and Places in the Global Economy, 11(1), 166-185. https:// doi.org/10.1108/JEC-01-2015-0005

Manfield, R.C., Newey, L.R. (2018). Resilience as an entrepreneurial capability: Integrating insights from a crossdisciplinary comparison. International Journal of Entrepreneurial Behaviour and Research, 24(7), 1155-1180. https://doi.org/10.1108/IJEBR-11-2016-0368

Martinelli, E., Tagliazucchi, G., Marchi, G. (2018). The resilient retail entrepreneur: dynamic capabilities for facing natural disasters. International Journal of Entrepreneurial Behavior \& Research, 24(7), 1222-1243. https://doi. org/10.1108/IJEBR-11-2016-0386

Metcalfe, M. (2005). Conjecture-first' problem solving. Systems Research and Behavioral Science, 22(6), 537-546. https://doi.org/10.1002/sres.654

Mitchell, A. (2013). Risk and Resilience: From Good Idea to Good Practice. OECD Development Co-Operation, Working Paper 13. https://doi.org/10.1787/22220518 
Moher, D., Liberati, A., Tetzlaff, J., Altman, D.G., The PRISMA Group (2009). Preferred Reporting Items for Systematic Reviews and Meta-Analyses: The PRISMA Statement, PLoS Med, 6(7), e1000097. https://doi.org/10.1371/ journal.pmed.1000097

Monllor, J., Murphy, P.J. (2017). Natural disasters, entrepreneurship, and creation after destruction: A conceptual approach. International Journal of Entrepreneurial Behaviour and Research, 23(4), 618-637. https://doi. org/10.1108/IJEBR-02-2016-0050

Morrison, C., Ramsey, E., Bond, D. (2017). The role of social entrepreneurs in developing community resilience in remote areas. Journal of Enterprising Communities: People and Places in the Global Economy, 11(1), 95-112. https://doi.org/10.1108/JEC-02-2015-0020

Roundy, P.T., Brockman, B.K., Bradshaw, M. (2017). The resilience of entrepreneurial ecosystems. Journal of Business Venturing Insights, 8, 99-104. https://doi.org/10.1016/j.jbvi.2017.08.002

Sienkiewicz-Małyjurek, K. (2015). Skuteczne zarządzanie kryzysowe, Warszawa: Difin.

Steyaert, C., Katz, J. (2004). Reclaiming the space of entrepreneurship in society: geographical, discursive and social dimensions. Entrepreneurship \& Regional Development, 16(3), 179-196. https://doi. org/10.1080/0898562042000197135

Tatham, P., Houghton, L. (2011). The wicked problem of humanitarian logistics and disaster relief aid. Journal of Humanitarian Logistics and Supply Chain Management, 1(1), 15-31.https://doi.org/10.1108/20426741111122394

United Nations (2007). Hyogo Framework for Action 2005-2015: Building the Resilience of Nations and Communities to Disasters. Extract from the final report of the World Conference on Disaster Reduction (A/CONF.206/6), Geneva: United Nations.

Ustawa z dnia 26 kwietnia 2007 r. o zarządzaniu kryzysowym (Dz. U. 2007, nr 89, poz. 590 z późn. zm.).

Vlasov, M., Bonnedahl, K.J., Vincze, Z. (2018). Entrepreneurship for resilience: embeddedness in place and in trans-local grassroots networks. Journal of Enterprising Communities: People and Places in the Global Economy, 12(3), 374-394. https://doi.org/10.1108/JEC-12-2017-0100

Williams, T.A., Shepherd, D.A. (2016). Building resilience or providing sustenance: different paths of emergent ventures in the aftermath of the Haiti earthquake. Academy of Management Journal, 59(6), 2069-2102. https://doi.org/10.5465/amj.2015.0682

Williams, T.A., Gruber, D.A., Sutcliffe, K.M., Shepherd, D.A., Zhao, E.Y. (2017). Organizational response to adversity: fusing crisis management and resilience research streams. The Academy of Management Annals, 11(2), 733-769. https://doi.org/10.5465/annals.2015.0134

Zahra, S.A., Gedajlovic, E., Neubaum, D.O., Shulman, J.M. (2009). A Typology of Social Entrepreneurs: Motives, Search Processes and Ethical Challenges. Journal of Business Venturing, 24, 519-532. https://doi.org/10.1016/ j.jbusvent.2008.04.007

\section{Resilience and entrepreneurship in emergency management}

Summary: The concepts of resilience and entrepreneurship in emergency management can contribute to increasing the ability to cope with threats. However, research and analysis in this area are limited. Research on resilience and entrepreneurship in emergency management has largely focused on the impact of these concepts on emergency management, with limited attempts to find out how they interact together. For this reason, the aim of this article is to systematize the knowledge of the role of resilience and entrepreneurship in emergency management and to establish mutual relations between these concepts. The aim of this article was achieved based on a systematic literature review using the PRISMA Group methodology. As a result, the characteristics and impact of both resilience and entrepreneurship on emergency management were presented, the importance of these concepts in social terms was shown, and the mutual interactions between them were identified. The obtained results indicate that emergencies constitute change accelerators that create opportunities for social and public entrepreneurship development. Resilience and entrepreneurship interact; together they create better abilities to deal with threats.

Keywords: resilience; social resilience; entrepreneurship; social entrepreneurship; emergency management, systematic literature review

JEL codes: $\mathrm{H} 12, \mathrm{H} 75, \mathrm{H} 84, \mathrm{~L} 38$ 


\section{Informacje o autorce}

Katarzyna Sienkiewicz-Małyjurek, prof. PŚ dr hab.

ORCID: 0000-0002-0915-5776

Katedra Zarządzania i Logistyki

Wydział Organizacji i Zarządzania

Politechnika Śląska

ul. Roosevelta 26, 41-800 Zabrze

e-mail: katarzyna.sienkiewicz-malyjurek@polsl.pl

\section{Prawa autorskie i licencja / Copyright and License}

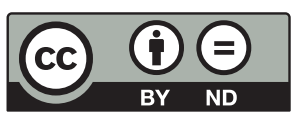

Publikacja na licencji Creative Commons Uznanie autorstwa Użycie niekomercyjne - Bez utworów zależnych 4.0 Międzynarodowe (CC BY-ND 4.0) http://creativecommons.org/licenses/by-nc-nd/4.0/deed/pl

This work is published under the terms of the Creative Commons

Attribution - NoDerivetives International (CC BY-ND 4.0) License http://creativecommons.org/licenses/by-nc-nd/4.0

Wydane przez Uniwersytet Ekonomiczny w Krakowie. Małopolska Szkoła Administracji Publicznej

Published by Cracow University of Economics - Krakow, Poland. Małopolska School of Public Administration of the Cracow University of Economics 